\title{
RISIKO DAN REFLEKSIVITAS GAY TERHADAP KEKERASAN (Studi Kasus pada Komunitas Gay di Surakarta)
}

\author{
Vebrianti Rahayu ${ }^{1}$, Argyo Demartoto ${ }^{2}$ \\ Program Studi Sosiologi Fakultas Ilmu Sosial dan Politik \\ Universitas Sebelas Maret Surakarta Indonesia \\ Email ${ }^{1}$ : vebrianti98@gmail.com,Email²: argyodemartoto_fisip@staff.uns.ac.id
}

\begin{abstract}
Gay is a minority group the existence of which is still unacceptable to the society. It puts the gay into a group vulnerable to violence risk. The objective of research is to study the risk and the reflexivity of violence in gay community in Surakarta. This qualitative with case study approach took place in Surakarta. The sampling technique used was purposive sampling one. The informant of research consisted of chairperson and administrators of Surakarta Gaya Mahardhika Foundation, gays becoming the victim of violence, community fellow members, and administrators of Mitra Alam Surakarta NGO. Data was collected through observation, in-depth interview, and documentation. To validate data, source triangulation was used. Technique of analyzing data used was Miles and Huberman's interactive model of analysis with Ulrich Beck's Risk Society theory.

The result of research showed that violence risk encountered by gay in Surakarta included physical violence such as being thrown with sharp weapon, being struck and slapped; physical/emotional violence such as cynical and disliking view, expulsion, threat and negative stigma intended to gay organization; sexual violence such as sexual abuse conducted by police officer by touching the victim's body organ; economic violence such as money and product expropriation by sexual partner; and verbal violence such as being insulted and mocked by some people on the street. The effect of violence consisted of physical effect such as bruise, gash, and pain still felt until today, and physical effect such as fear, trauma, discomfort and fidget, disappointment, resentfulness, anger, pique, and regret. The reflectivity of gay in dealing with violence included interacting or looking for acquaintance or partner more alertly and selectively; adapting, comporting; building intimacy an self-image by conducting positive activities within society; conducting homosexual activity more carefully such as fulfilling their sexual need in their known place rather than doing it in opened space that has been known by mass organization; and providing advocacy to the gay becoming the victim of violence.
\end{abstract}

Keywords: Gay Community, Violence Risk, Reflexivity

Abstrak: Kaum gay merupakan kelompok minoritas karena masih belum diterima keberadaannya dalam masyarakat. Hal tersebut menempatkan gay ke dalam kelompok yang rentan terhadap risiko mendapat perlakukan kekerasan. Tujuan penelitian ini untuk mengkaji risiko dan refleksivitas terhadap kekerasan pada komunitas gay di Surakarta. Penelitian kualitatif dengan pendekatan studi kasus ini dilakukan di Surakarta. Teknik pengambilan sampel dengan teknik purposive sampling. Adapun informan penelitian terdiri dari ketua dan pengurus Yayasan Gaya Mahardhika Surakarta, gay korban kekerasan, teman sesama komunitas, serta pengurus LSM Mitra Alam Surakarta. Data dikumpulkan dengan observasi, wawancara mendalam dan dokumentasi. Untuk menguji validitas data dengan triangulasi sumber. Teknik analisis data menggunakan model analisis interaktif dari Miles dan Huberman dengan teori Masyarakat Risiko dari Ulrich Beck. 
Hasil penelitian menunjukkan bahwa risiko kekerasan yang dialami gay di Surakarta berupa, kekerasan fisik seperti dilempar senjata tajam, dipukul dan ditempeleng; kekerasan psikologis/ emosional, seperti pandangan sinis dan tidak suka, pengusiran, serta ancaman dan stigma negatif yang ditujukan kepada organisasi gay; kekerasan seksual, seperti pelecehan seksual dengan meraba bagian tubuh korban oleh oknum polisi; kekerasan ekonomi, seperti pemaksaan terhadap uang dan barang oleh partner seksual; serta kekerasan verbal, seperti diumpati kata kasar, dibentak, dan diejek oleh orang saat dijalan. Dampak dari kekerasan terdiri dari, dampak fisik seperti memar, luka sobek, dan rasa sakit yang masih terasa sampai sekarang, dan dampak psikis, seperti takut, trauma, rasa tidak aman dan tenang, kecewa, merasa tidak terima dan sakit hati, merasa marah, kesal, dan menyesal. Refleksivitas gay dalam menangani kekerasan diantaranya, lebih waspada dan selektif dalam berinteraksi atau mencari kenalan atau pasangan; beradaptasi, membawa diri, membangun kedekatan dan citra diri dengan melakukan kegiatan positif dalam masyarakat; lebih hati-hati dalam melakukan aktivitas homoseksual seperti memenuhi kebutuhan seksualnya dengan langsung di tempat yang sudah dikenal; tidak mangkal di tempat terbuka dan yang sudah diketahui ormas, serta advokasi bagi gay korban kekerasan oleh komunitas gay.

Kata Kunci: Komunitas Gay, Risiko Kekerasan, Refleksivitas

\section{PENDAHULUAN}

Fenomena Lesbian, Gay, Biseksual dan Transgender (LGBT) menjadi isu sosial yang saat ini banyak diperbincangkan dalam kehidupan sosial masyarakat di dunia. Pemberitaan media baik nasional juga internasional juga turut mendukung dalam menyuguhkan beritaberita mengenai homoseksual. Sehingga berbagai pemberitaan media mengenai homoseksual sekarang ini, tidak luput menjadi bahan diskusi dan perdebatan oleh masyarakat serta para ahli di Indonesia, karena homoseksual masih menimbulkan dilema pro dan kontra dalam masyarakat. Homoseksualitas mengacu pada perasaan tertarik, secara perasaan atau erotik, baik secara predominan maupun eksklusif terhadap orang-orang yang berjenis kelamin sama, dengan atau tanpa adanya hubungan fisik (Oetomo, 2001). Kartini Kartono juga mengungkapkan bahwa homoseksualitas adalah ketertarikan secara perasaaan ataupun hasrat untuk berhubungan seks dengan jenis kelamin yang sama (Kartono, 1989). Secara umum manusia mempunyai orientasi seksual atau ketertarikan terhadap lawan jenisnya. Pria tertarik pada wanita dan begitu sebaliknya, wanita memiliki ketertarikan pada pria. Ini hal yang wajar dalam masyarakat dan disebut sebagai heteroseksual. Namun pada orang-orang tertentu, ada yang memiliki orientasi terhadap sesama jenis atau disebut homoseksual. Homoseksual merupakan aktivitas seksual dimana pasangan seksual yang dipilih berasal dari sesama jenis. Ketertarikan antar sesama pria disebut sebagai gay, dan sesama wanita disebut lesbian. Sehingga gay dan lesbian dikelompokkan ke dalam kaum homoseksual (Demartoto, 2010).

Identitas seksual yang ditunjukkan kaum homoseksual, seringkali mendapat penolakan dari masyarakat, termasuk di Indonesia. Dalam masyarakat Indonesia masih tertanam kuat nilai heteronormatif dalam masyarakat. Kitzinger (dalam Messerschmidt, 2012) menjelaskan pengertian heteronormativitas memandang bahwa heteroseksual merupakan satu-satunya seksualitas yang alamiah, normal dan umum. Dalam aturan heteronormatif, laki-laki diharuskan macho dan menikah dengan perempuan. Oleh karena itu, membuat keberadaan homoseksual dianggap hal yang menyimpang di Indonesia. Masyarakat 
Indonesia masih melekat dengan budaya timur, berbeda dengan di negara barat, seperti negara Belanda dan Amerika Serikat saat ini yang masyarakatnya telah menerima keberadaan kaum homoseksual dan menghalalkan pernikahan sesama jenis. Hal ini menjadi sebuah masalah, yaitu munculnya istilah homophobic atau homophobia yakni merupakan rasa takut untuk berada dalam jarak dekat dengan pria maupun wanita homoseksual diikuti dengan perasaan takut, kebencian, dan ketidaktoleranan yang irasional dari individu heteroseksual kepada pria maupun wanita homoseksual (Adams; Wright; Lohr, 1996). Weinberg mendefinisikan homophobia sebagai ketakutan terhadap homoseksual dan bentuk-bentuk lain yang menunjukkan keintiman dua jenis kelamin yang sama (Allgeier, 1991). Hal seperti menimbulkan sikap diskriminatif, prasangka buruk terhadap kaum homoseksual yang dianggap ganjil, sakit, dan menyalahi kodrat (Tan, 2005). Dengan demikian, kelompok homoseksual yang hidup dalam masyarakat heteronormatif dihadapkan pada risiko-risiko yang tidak semua orang mengerti dan risiko tidak diterima karena identitas seksualnya. Risiko-risiko yang muncul akibat perkembangan zaman baik kultural maupun struktural tidak dapat dihindarkan lagi. Risiko telah menjadi bagiandari kehidupan manusia (Beck, 1992; Sindhunata, 2000).

Secara umum homoseksual rentan terhadap kekerasan dan risiko dalam berbagai bentuk lainnya, antara lain terinfeksi HIV/AIDS dan penyakit menular seksual lainnya, diskriminasi serta stigma masyarakat. Banyak stigma terhadap kaum homoseksual yang berlaku di dalam masyarakat. Sehingga kelompok homoseksual dalam kehidupan sehari-hari dapat dikatakan mendapatkan tekanan sosial lebih besar daripada kelompok heteroseksual. Kelompok homoseksual harus menghadapi kenyataan secara intern dan ekstern. Dalam konteks homoseksual gay, secara intern, adanya konflik intern dalam kelompok sesama homoseksual seperti kekerasan dalam sesama komunitas ataupun dalam hubungan pasangan homoseksual. Sedangkan secara ekstern, penolakan oleh mayoritas kelompok heteroseksual terhadap praktik homoseksual, seperti diskriminasi yang berujung kekerasan dari masyarakat heteroseksual atau bahkan dari keluarga. Sebagai bagian dari homoseksual, kaum gay merupakan kelompok minoritas yang didominasi kelompok mayoritas heteroseksual. Keberadaannya masih belum diterima dalam masyarakat. Keberadaan mereka adalah suatu yang nyata dan disadari sebagai sebuah realita dalam masyarakat. Namun sampai saat ini, realita menunjukkan masih adanya perilaku tidak menyenangkan terhadap gay, mereka belum mendapatkan kesempatan yang sama seperti heteroseksual dalam beberapa aspek kehidupan karena orientasi seksualnya sebagai penyuka sesama jenis. Melihat kasus-kasus kekerasan pada gay di Indonesia disebabkan karena konsep pandangan mayoritas terhadap minoritas. Penerimaan kaum gay yang masih kontroversial menimbulkan banyak diskriminasi seperti kekerasan. Diskriminasi yang berikan kepada kaum gay dan tindak kekerasan terhadap kaum ini dilakkan karena perbedaan orientasi seksual mereka. Dalam penelitian Lembaga Sosial Masyarakat Arus Pelangi tahun 2013, yang merupakan sebuah lembaga swadaya masyarakat yang membela hak-hak kaum lesbian, gay, biseksual, dan transgender (LGBT), menunjukkan bahwa di Jakarta, Yogyakarta, dan Makassar 89,3\% LGBT pernah mendapat perlakuan diskriminasi yang berujung kekerasan. Tindak kekerasan yang diterima kelompok LGBT dikategorikan menjadi aspek fisik, psikis, seksual, ekonomi, dan budaya (BBC, 2014, para. 2). Kasus kekerasan tersebut tercatat sebanyak $79.1 \%$ dalam bentuk kekerasan psikis, $46.3 \%$ dalam bentuk kekerasan fisik, 26.3\% dalam bentuk kekerasan ekonomi, $45.1 \%$ dalam bentuk kekerasan seksual, dan $63.3 \%$ dalam bentuk kekerasan budaya. Bentuk kekerasan budaya yang dialami termasuk pengusiran dari rumah atau kos, dituntut untuk menikah, dan dipaksa untuk menikah dengan orang yang tidak disukai; dan pelaku utama kekerasan budaya adalah keluarga (76.4\%) dan teman (26.9\%). Bentuk kekerasan psikis yang dialami termasuk 
ancaman, diusir, diawasi, disakiti, dikirimi pesan gelap, dikuntit, dan dirusak barangnya, yang dilakukan oleh orang tidak dikenal (46\%), keluarga (41.9\%) dan teman (38.5\%). Waria paling banyak mengalami kekerasan seksual (49\%) disusul dengan Gay (30.5\%), khususnya yang dilakukan oleh orang tidak dikenal, tamu, preman, dan teman. Banyak dari kasus kekerasan yang dialami LGBT terjadi dalam bentuk bullying saat di Sekolah, yang berdampak pada penurunan performa belajar, meninggalkan sekolah, dan berfikir atau bahkan mencoba untuk bunuh diri. 17.3\% LGBT pernah melakukan usaha bunuh diri, dan 16.4\% mencobanya lebih dari satu kali. 65.2\% LGBT mencari bantuan ke teman saat mengalami kekerasan dan hanya $18.7 \%$ yang mencari bantuan ke keluarga. 29.8\% LGBT memilih untuk tidak mencari bantuan saat mengalami kekerasan. Data-data ini menunjukan bahwa komunitas LGBT sangatlah rentan terhadap kekerasan, stigma, dan diskriminasi yang kerap terjadi di ruang publik dan ruang domestik. (Tempo.co, 2016).

Diskriminasi yang berujung kekerasan memunculkan suatu gerakan LGBT di Indonesia untuk menuntut pengakuan identitas homoseksual dalam aspek nasional maupun internasional. Salah satu gerakan seperti yang termuat dalam dalam Human Rights Watch World Report tahun 2008, prinsip-prinsip Yogyakarta atau Yogyakarta Principles tentang Penerapan Hukum Hak Asasi Manusia Internasional dalam kaitannya dengan Orientasi Seksual dan Identitas Gender yang merupakan sekumpulan prinsip-prinsip yang mengatur orientasi seksual dan identitas gender, ditujukan untuk menerapkan standar hukum hak asasi manusia internasional dalam mengatasi pelecehan hak asasi manusia terhadap lesbian, gay, biseksual dan transgender (LGBT), dan (secara sekilas) interseks. Prinsip-prinsip ini dikembangkan dalam pertemuan antara Komisi Ahli Hukum Internasional, International Service for Human Rights dan ahli hak asasi manusia dari seluruh dunia di Universitas Gadjah Mada di Yogyakarta pada tanggal 6-9 November 2006. Memuat 29 prinsip diadopsi dengan suara bulat oleh para ahli, bersama dengan rekomendasi kepada pemerintah, lembaga antar pemerintah daerah, masyarakat sipil, dan PBB yang patut dipatuhi oleh suatu Negara terkait dengan orientasi seksual dan pengakuan identitas gender seseorang seperti hak atas keamanan seseorang (pasal 5), hak atas privasi (prinsip 6), dan seterusnya. Pada umumnya, gerakan tersebut dilakukan sebagai usaha untuk mewujudkan tatanan masyarakat atau sosial yang menghargai dan menghormati keberagaman seks, gender dan seksualitas.

Di Surakarta sendiri jumlah populasi gay cukup banyak. Mengacu pada perkiraan jumlah gay di Surakarta, Edy Wirastho, Aktivis Komunitas Peduli Sahabat dari Jakarta, yang dikutip dari Harianjogja.com (2016), bahwa jumlah kaum gay di Kota Surakarta lebih dari 5.000 orang. Angka tersebut diperoleh berdasarkan pendataan Dinas Kesehatan (Dinkes) Kota Surakarta tahun 2010. Jumlah tersebut murni jumlah gay di Kota Surakarta, belum termasuk waria dan lesbian. Kota Surakarta juga merupakan tempat yang sangat strategis bagi para gay untuk berkumpul. Hal tersebut dikarenakan Surakarta termasuk wilayah yang cukup dinamis dalam perkembangan sosial dan ekonominya. Perkembangan ini menjadi peluang para gay di Surakarta karena semakin banyak tempat-tempat yang dapat dijadikan perkumpulan mereka. Selain itu pengaruh urbanisasi dari kota-kota besar seperti Surabaya, Yogyakarta, dan Semarang ke Surakarta, hal ini dapat menyebabkan masuknya unsur-unsur budaya baru dan homoseksual merupakan salah satu unsur yang masuk ke wilayah Surakarta. Perkembangan homoseksual di Surakarta juga turut dipengaruhi oleh kemajuan teknologi informasi dan komunikasi. Apriliani (2018) mengatakan bahwa perkembangan teknologi dan informasi juga mendorong gay untuk semakin menunjukkan keterbukaanya mengenai identitas seksual dan orientasi seksual mereka. Media sosial menjadi salah satu ruang bagi komunitas gay untuk bekspresi, menemukan laki-laki sesama jenis, berbagi cerita termasuk dalam memenuhi kebutuhan seksualnya seperti dalam mencari partner atau pasangan 
seksual. Apriliani menambahkan bahwa tidak hanya WhatsApps, Instagram, Facebook, Twitter ataupun situs blog lainnya, melinkan sekarang sudah banyak aplikasi khusus bagi gay seperti Grindr, JackD, Hornet, ataupun GROWLr. Dengan adanya media sosial membuat identitas kaum gay menjadi lebih terbuka.

Tidak ada data spesifik yang menunjukkan jumlah kekerasan gay yang terjadi di Surakarta. Mereka tersembunyi dan menutup apa yang telah terjadi. Menurut Wahyuni (2012), bahwa kaum gay dalam masyarakat (luar komunitas gay) di Surakarta banyak yang mendapat kekerasan. Kekerasan kerap didapatkan dari keluarga, teman, tetangga, preman sampai kelompok-kelompok agama tertentu karena identitas seksual mereka. Hal ini menunjukkan bahwa kaum homoseksual termasuk gay didalamnya sangat rentan terhadap risiko mendapat kekerasan. Seharusnya, dengan adanya banyak keberagaman, mampu membuat kita untuk lebih saling menghargai keberagaman tersebut, bukan untuk mendiskriminasi atau melakukan tindak kekerasan. Namun, kuatnya kultur heteronormatif menimbulkan homophobia dalam masyarakat heteroseksual. Hal tersebut menimbulkan risiko mendapat kekerasan yang terjadi terhadap gay di Surakarta.

Kaum gay merupakan kelompok minoritas karena masih belum diterima keberadaannya dalam masyarakat. Hal tersebut menempatkan gay ke dalam kelompok yang rentan terhadap risiko mendapat perlakukan kekerasan. Gay berisiko menjadi korban kekerasan oleh mereka yang kontra dengan orientasi seksual gay. Konteks kekerasan terhadap gay tersebut dilihat menurut bentuk-bentuk kekerasan itu sendiri baik dari lingkup intern seperti oleh keluarga dan pasangan seksual mereka. Secara ekstern, yaitu masyarakat heteroseksual seperti aparatur negara, dan organisasi massa (ormas). Sehingga diperlukan refleksi berupa solusi baik berupa pikiran, renungan, sikap maupun tindakan berperan dalam mengantisipasi, mengurangi atau mengatasi dampak-dampak atau akibat-akibat dari risiko kekerasan yang dialami gay. Berdasarkan uraian diatas, mendorong peneliti untuk untuk melakukan penelitian secara mendalam mengenai bagaimana risiko, dampak serta refleksivitas terhadap kekerasan pada gay dalam lingkupnya sebagai anggota masyarakat dan anggota dalam komunitas gay. Dalam penelitian ini dilakukan pada Yayasan Gaya Mahardhika di Surakarta.

\section{METODE PENELITIAN}

Penelitian ini dilakukan di Surakarta, dikarenakan Kota Surakarta keberadaan kaum gay masih belum sepenuhnya diterima masyarakat sehingga beberapa dari mereka menjadi korban kekerasan. Secara spesifik penelitian dilakukan di Yayasan Gaya Mahardhika Surakarta. Yayasan Gaya Mahardhika merupakan organisasi LGBT terbuka di Surakarta dan menerima homoseksual apa adanya, seperti LGBT dengan HIV/AIDS. Penelitian ini merupakan penelitian deskriptif kualitatif dengan pendekatan studi kasus. Teknik pengambilan sampel yang digunakan adalah purposive sampling dengan informan penelitian terdiri dari ketua dan pengurus Yayasan Gaya Mahardhika Surakarta, gay korban kekerasan, teman sesama komunitas, serta pengurus LSM Mitra Alam Surakarta. Data dikumpulkan melalui wawancara mendalam dengan seluruh informan dan mengobservasi karakteristik informan, serta mengkaji dokumen terkait kekerasan terhadap gay. Untuk menguji validitas data dilakukan triangulasi sumber membandingkan jawaban informan lain dalam mengcroscek data yang diperoleh langsung data sehingga antara data yang satu terkontrol oleh data yang lain. Teknik analisis data menggunakan model analisis interaktif dari Miles dan Hubermas dengan teori Masyarakat Risiko dari Ulrich Beck., yang terdiri dari tiga skema secara bersamaan, yaitu reduksi data, penyajian data, penarikan kesimpulan. 


\section{HASIL PENELITIAN DAN PEMBAHASAN \\ Risiko Kekerasan pada Gay di Surakarta}

Komunitas gay merupakan komunitas atau anggota masyarakat yang berisiko di era posmodern ini. Masyarakat risiko adalah masyarakat yang telah mampu bangkit atas masalah di masyarakat dengan menyadari dan merespon (reflexive modernity) akan risiko dimana keadaan yang tidak pasti, berbagai kemungkinan buruk dapat terjadi, dan penuh risiko yang dapat muncul di segala kondisi, tempat, dan waktu yang tidak mudah diprediksi (Beck, 1992; Demartoto, 2013). Dengan demikian, gay sebagai anggota masyarakat berisiko secara mandiri dapat merespon kondisi atas risiko kekerasan yang tidak pasti. Pemahaman, persepsi, dan respon mengenai risiko diambil sesuai dengan konteks sosial (York et al., 2003). Konteks sosial dalam penelitian ini adalah gay yang mengalami kekerasan karena heteronormativitas dalam masyarakat.

Dalam realita, gay merupakan kaum minoritas yang keberadaannya masih dihadapkan dengan dilema di tengah masyarakat. Keberadaan mereka belum diterima sepenuhnya oleh masyarakat. Padahal keberadaan mereka adalah suatu yang nyata dan disadari sebagai sebuah realita dalam masyarakat. Mereka minoritas yang didominasi kelompok mayoritas heteroseksual. Kondisi demikian terjadi karena orientasi seksual yang diakui secara umum oleh masyarakat adalah ketertarikan seksual terhadap lawan jenis atau heteroseksual. Keberagaman orientasi seksual belum banyak dipahami oleh masyarakat pada umumnya sehingga orang-orang yang bukan heteroseksual masih sering mendapat diskriminasi maupun kekerasan dari berbagai pihak.

Seperti halnya gay, dalam realita mereka hidup dalam masyarakat heteronormativitas. Dari hasil penelitian dapat diketahui bahwa Surakarta berpotensi besar terhadap pelanggaran terhadap hak-hak gay sebagai salah satu kelompok LGBT. Masyarakat Surakarta yang masih memegang kuat nilai-nilai budaya serta agama yang kuat. Nilai-nilai tersebut merupakan nilai mayoritas yang dipegang teguh dalam masyarakat, diantaranya heteronormativitas dan budaya patriaki. Heteronormativitas pada Masyarakat Surakarta juga cukup kuat. Heteronormativitas memandang bahwa heteroseksualitas adalah bentuk hubungan yang sah. Oleh karena itu, membuat keberadaan homoseksual termasuk gay dianggap hal yang masih menyimpang dan belum diterima di Surakarta. Sama halnya dalam konteks keluarga, heteronormativitas juga masih dipegang teguh oleh sebagian besar orang tua. Dari hasil penelitian tidak jarang gay yang menutup diri terkait identitasnya terhadap orang tua. Homoseksual cenderung menutup diri karena takut terhadap penolakan dari lingkunganya (Demartoto, 2013). Walaupun telah coming out, gay dalam hal ini tetap membatasi diri dengan orang tuanya. Bahkan gay memilih berpura-pura menjadi hereroseks di hadapan keluarganya.

Kekerasan terhadap gay juga terjadi karena budaya patriarki yang dipegang teguh masyarakat di Indonesia, dimana laki-laki dinomorsatukan kedudukannya. Akibatnya, ketika ada laki-laki yang feminine, dan menyukai sesama jenis, hal itu dianggap menyimpang. Demikian itu membuat keberadaan homoseksual termasuk gay dianggap hal yang masih menyimpang dan belum diterima di Surakarta.

Sehingga kelompok gay dalam kehidupan sehari-hari dapat dikatakan mendapatkan tekanan sosial lebih besar daripada kelompok heteroseksual. Karena pandangan mayoritas terhadap minoritas tersebut menyebabkan terjadinya kekerasan terhadap gay. Kasus-kasus kekerasan yang terjadi pada gay juga disebabkan karena konsep pandangan mayoritas terhadap minoritas. Penerimaan kaum gay yang masih kontroversial menimbulkan banyak diskriminasi seperti kekerasan. Disamping itu, hukum dan sosial Indonesia juga belum bisa menerima keberadaan mereka dan menjamin keamanannya. Konsekuensinya kekerasan 
terhadap komunitas gay hampir tidak pernah dilaporkan. Risiko kekerasan tersebut tidak hanya konsekunsi gay sebagai kelompok minoritas, namun juga kekerasan dalam sesama komunitas, seperti kekerasan oleh pasangannya.

\section{Bentuk-bentuk Kekerasan Gay di Surakarta}

Dari hasil identifikasi kasus kekerasan yang dialami gay di Surakarta, bentuk-bentuk kekerasan yang dialami gay diantaranya meliputi kekerasan fisik, psikologis/emosional, seksual, ekonomi dan verbal. Pelakunya beragam, mulai dari ormas keagamaan tertentu, polisi, hingga orang tua. Berdasarkan hasil penelitian bentuk-bentuk kekerasan yang dialami gay adalah sebagai berikut.

a) Kekerasan Fisik

Kekerasan fisik merupakan kekerasan yang menggunakan kekuatan fisik secara instensif yang berpotensi menyebabkan luka, bahaya, cacat dan kematian. Dari hasil penelitian menunjukkan kekerasan fisik yang dialami gay meliputi dilempar senjata tajam oleh pasangan sendiri, dipukul oleh ormas agama dan ditempeleng oleh orang tua.

b) Kekerasan Psikiologis/emosional

Kekerasan psikologis atau emosional merupakan kekerasan yang dilakukan melalui bahasa tubuh. Dalam penelitian ini kekerasan psikis berupa seperti mendapat pandangan sinis dan tidak suka, diusir, bahkan diancam oleh teman dan masyarakat sekitar. Ada juga kekerasan pisikis yang berbasis komunitas. Kekerasan ditujukan tidak hanya pada individu gay, melainkan juga Yayasan Gaya Mahardhika sebagai komunitas yang menaungi gay. Kekerasan tersebut berupa stigma negatif bahwa gay dapat menular ke masyarakat. Yayasan dianggap berpotensi membuat masyarakat menjadi bagian dari LGBT.

\section{c) Kekerasan Ekonomi}

Kekerasan ekonomi adalah kekerasan yang terjadi ketika pelaku kekerasan mengontrol secara penuh uang korban dan sumber-sumber ekonomi lainnya (Putri, 2012). Dalam penelitian ini, kekerasan ekonomi yang dialami gay yang berkaitan dengan materi, dimana gay harus menyerahkan materi secara paksa. Kekerasan ini berupa dimintai uang dan barang secara paksa oleh partner seksualnya.

d) Kekerasan Seksual

Kekerasan seksual menurut Putri (2012), merupakan upaya melakukan hubungan seksual yang melibatkan seseorang yang tidak memiliki kemampuan untuk memahami kelaziman/ kebiasaan atau keadaan dari aksi tersebut, tidak mampu untuk menolak, atau tidak mampu mengkomunikasikan ketidakinginan untuk turut dalam hubungan seksual dan lainlain. Dalam penelitian ini kekerasan seksual berupa pelecehan dari oknum polisi saat operasi kendaraan bermotor.

\section{e) Kekerasan Verbal}

Menurut Putri (2012), kekerasan verbal adalah kekerasan yang dilakukan lewat katakata, contohnya: membentak, memaki, menghina, menjuluki, meneriaki, memfitnah, menyebar gosip, menuduh, menolak dengan kata-kata kasar, mempermalukan di depan umum dengan lisan, dan lain-lain. Dalam penelitian ini kekerasan verbal yang dialami gay di Surakarta seperti dimaki dan dibentak saat di jalan hingga diumpati kata kasar saat dijalan. Selain itu gay juga dibentak, diolok-olok dan diejek teman-temannya. 


\section{Dampak Kekerasan terhadap Gay di Surakarta}

Kekerasan dalam bentuk apapun dapat menimbulkan dampak bagi korbannya, demikian pula dalam kasus kekerasan terhadap gay. Kekerasan yang terjadi pada gay membawa dampak tertentu bagi setiap korban. Berdasarkan hasil wawancara yang telah dilakukan terhadap 6 orang informan, dapat diketahui bahwa dampak kekerasan terhadap gay meliputi dampak fisik dan dampak psikis. Dari dampak tersebut, dampak yang paling dominan dialami gay yang mengalami kekerasan adalah dampak psikis. Dampak fisik sendiri sebagian besar disebabkan oleh kekerasan fisik. Dimana kekerasan fisik dapat mengakibatkan korban mengalami kerusakan fisik seperti memar dan sakit. Korban kekerasan jenis ini biasanya tampak secara langsung pada fisik korban seperti luka memar, berdarah, patah tulang, pingsan dan bentuk lain yang kondisinya lebih berat. Kekerasan nyata yang dapat dilihat, dirasakan oleh tubuh. Sedangkan dampak psikis berupa trauma, sakit hati, kecewa, dendam, harga diri yang terluka, terhina, dan sebagainya. Kekerasan yang dialami gay menimbulkan beberapa dampak, yaitu sebagai berikut.

a) Dampak fisik, seperti memar, luka sobek, dan rasa sakit yang masih terasa sampai sekarang.

b) Dampak psikis, seperti takut, trauma, rasa tidak aman dan tenang, kecewa, merasa tidak terima dan sakit hati, merasa marah, kesal, sakit hati dan menyesal.

\section{Refleksivitas Gay terhadap Risiko Kekerasan}

Ada 3 risiko yang dikemukakan oleh Ulrich Beck, yakni risiko fisik-ekologis (physical-ecological risk), risiko sosial (social risk), dan risiko mental (psyche risk) (Beck, 1992). Risiko kekerasan yang berhasil diidentifikasi peneliti dialami gay di Surakarta berupa kekerasan fisik, psikologis/emosional, seksual, ekonomi, dan verbal. Kekerasan fisik cenderung dikatakan sebagai suatu risiko fisik. Bentuk kekerasan ini seperti perlakukan kekerasan dari pacarnya dengan melempar senjata tajam pada korban, pemukulan oleh orang tua terhadap karena tidak menerima orentasi seksual anaknya', serta gay yang tertangkap razia dan mengalami pemukulan membabi buta oleh ormas keagamaan.

Risiko kekerasan psikologis/emosional juga menjadi risiko kekerasan yang ditemukan pada gay di Surakarta. Kekerasan psikis yang terjadi sejatinya dapat berkontribusi dalam peningkatan risiko bagi kesehatan mental gay. Woodfort dkk (2014) mengungkapkan bahwa adanya pengalaman seperti penganiayaan, dan segala macam bentuk diskriminasi meningkatkan risiko bagi kesehatan mental yang buruk di kalangan seksual minoritas. Dalam penelitian ini, risko mental tampak pada kekerasan yang berbentuk psikologis/emosional seperti gay dipandang sinis dan tidak suka, diusir, diancam, bahkan masyarakat memberikan stigma negatif terhadap yayasan. Risiko kekerasan seksual seperti pelecehan oleh oknum polisi. Korban diraba dan dipegang bagian tubuhnya. Sedangkan risiko kekerasan ekonomi dimana korban dipaksa menyerahkan uang dan handphone oleh partner seksualnya. Selain itu juga ditemukan kekerasan verbal yang dialami gay, yaitu diumpati kata kasar, dibentak, diolok-olok dan diejek oleh masyarakat sekitar, yang menganggap gay tersebut telah melanggar norma. Hasil penelitian tersebut sesuai dengan pendapat Ulrich Beck (1992) bahwa berbagai risiko kekerasan yang akan ditimbulkan diantaranya risiko kekersan fisik, psikologis/emosional, seksual, ekonomi, dan verbal.

Dalam penelitian ini sejalan dengan pemikiran Ulrich Beck (1992) mengenai refleksivitas, gay secara mandiri dapat merespon kondisi atas risiko kekerasan yang tidak pasti. Risiko kekerasan yang terjadi pada gay mendorong adanya suatu refleksivitas tertentu bagi setiap korban. Berdasarkan hasil penelitian, gay tahu tentang risiko kekerasan yang akan dialami di tengah masyarakat heteronormativitas dan menyadari bahwa mereka merupakan 
kelompok yang rentan terhadap risiko mendapat perlakukan kekerasan. Hal tersebut didukung dengan pendapat Dank (2018) bahwa remaja lesbian, gay, dan biseksual memiliki risiko yang lebih tinggi untuk semua jenis kekerasan dengan kekerasan (dan hampir semua jenis kekerasan dalam pacaran), dibandingkan dengan remaja heteroseksual. Gay berusaha mengatasi risiko kekerasan dengen berbagai upaya-upaya dalam tindakan sebagai bentuk respon atas kekerasan. Informan menyatakan lebih waspada dalam berinteraksi dengan masayarakat, mencari kenalan atau pasangan dengan lebih selektif, agar tidak kekerasan itu tidak terulang lagi. Selain itu, pembawaan diri di masyarakat juga penting dalam membangun kedekatan dengan masyarakat. Pendekatan tersebut dapat diwujudkan dengan melakukan berbagai bentuk kegiatan positif dan beradaptasi seacra sosial dilingkungan masyarakat. Membangun citra diri dengan masyarakat dengan melakukan kegiatan kemasyarakatan. Selain itu, Yayasan Gaya Mahardhika pun berusaha memberikan manfaat bagi orang di sekitarnya, seperti keluarga, rekan kerja, ataupun masyarakat luas demi memenuhi tuntutan masyarakat dan menghindari risiko kekerasan terhadap yayasan. Bermanfaat bagi orang lain ini dilakukan dengan turut andil dalam suatu kegiatan dalam masyarakat, seperti bergabung bersama karang taruna di desa dalam rangka kegiatan HUT RI, dan bergabung dalam kepengurusan RT dan RW. Menurut peneliti, dengan turut andil dalam berbagai kegiatan positif di masyarakat, anggota Gaya Mahardhika telah melakukan adaptasi demi memenuhi tuntutan masyarakat.

Informan lain juga mengatakan lebih hati-hati dalam melakukan aktivitas homoseksual, seperti memenuhi kebutuhan seksualnya dengan langsung di tempat yang sudah dikenal. Kemudian bagi gay yang sering mangkal di hotspot, memberikan jawaban dengan tidak mangkal di tempat terbuka dan yang sudah diketahui ormas. Selain itu, dari komunitas gay juga melakukan advokasi bagi gay agar mendapat keadilan hukum atas kekerasan yang dialami.

Upaya dalam menangani risiko ini memunculkan ketidakpastian baru atau masalah baru sebagai efek boomerang. Efek boomerang yakni sebuah pengaruh dari risiko yang menyerang kembali kepada pembuatnya. Dalam hal ini usaha gay untuk mengatasi risiko ini tidak dijamin oleh pemerintah. Belum adanya peraturan pemerintah yang jelas untuk menjamin dan melindungi keberadaan gay yang menahan upaya meminimalisir risiko kekerasan. Dari berbagai bentuk kasus kekerasan yang dialami oleh gay itu menunjukkan bahwa di Indonesia belum ada payung hukum yang konsisten atas norma-norma untuk menghormati, melindungi dan memenuhi hak-hak setiap orang, terlebih dalam kasus kekerasan berbasis orientasi seksual dan gender. Sangat sulit bagi gay untuk memperjuangkan haknya dalam keadilan hukum, ditambah lagi belum ada hukum yang jelas. Kasus pemukulan maupun pelecehan seksual yang dilakukan anggota kepolisian terhadap gay di Surakarta merupakan salah satu bukti bahwa aparatur negara menjadi bagian dari aktor kekerasan itu. Tentunya perlakuan tidak menyenangkan yang dialami oleh gay di Surakarta tersebut bukan kasus satu-satunya. Sebenarnya masih banyak kasus serupa lainnya yang mungkin belum terekspos. Selain itu, ormas keagamaan turut menjadi penyumbang terbesar bagi kekerasan terhadap gay yang terjadi di Surakarta, yang berupa pengusiran maupun kekerasan fisik.

Ketidakpastian hukum membuat tindakan kekerasan terhadap gay semakin menjadijadi karena seolah mempunyai legitimasi untuk berbuat kekerasan. Seperti diungkapkan oleh Levy (2017) yang mengatakan bahwa suatu kebijakan publik tentang hak-hak gay dan lesbian dapat mempengaruhi adanya kebencian dan kejahatan atas dasar orientasi seksual. Dimana ketidaksetaraan hukum meningkatkan kejahatan dan kebencian karena memberikan peluang diskursif untuk bias, diskriminasi, dan kekerasan. Kesataraan hukum, sebenarnya akan 
mengurangi kekerasan. Seperti halnya kekerasan terjadap gay yang terjadi di Surakarta, dimana pelaku kekerasan semakin menjadi karena seolah mempunyai legitimasi untuk berbuat kekerasan. Ketiadaan payung hukum yang melindungi mereka memungkinkan pihakpihak tertentu melakukan kekerasan terhadap gay.

\section{KESIMPULAN}

Gay juga merupakan kelompok minoritas karena masih belum diterima keberadaannya dalam masyarakat. Hal tersebut menempatkan gay ke dalam kelompok yang rentan terhadap risiko mendapat perlakukan kekerasan. Sehingga kekerasan menjadi risiko bagi gay. Gay dalam hal ini sulit untuk memprediksi risiko kekerasan seperti apa yang akan diterimanya karena kondisi yang tidak pasti, yakni keberadaannya yang masih menuai pro dan kontra masyarakat karena berbenturan dengan sistem nilai masyarakat, serta aturan yang masih belum jelas. Ketidakpastian ini merupakan sebuah risiko yang dapat yang sebelumnya telah terjadi atau yang kemungkinan dapat terjadi. Dari hasil analisis menggunakan teori Masyarakat Risiko dari Ulrich Beck, dimana Komunitas gay merupakan komunitas atau anggota masyarakat yang berisiko di era posmodern ini. Akan tetapi menurut Beck (1992), sebagai masyarakat yang berisiko, komunitas gay adalah masyarakat yang telah mengenal bagaimana mengatasi keadaan yang tidak pasti sesuai dengan kemampuan kreatifivitasnya. Hasil penelitian ini sesuai dengan teori Ulrich Beck tentang masyarakat berisiko yakni kebangkitan atas masalah di masyarakat yang membawa kesadaran bahwa kita hidup dimasa yang dicirikan dengan keadaan yang tidak pasti, berbagai kemungkinan buruk dapat terjadi, dan penuh risiko yang dapat muncul di segala kondisi, tempat, dan waktu yang tidak mudah diprediksi. Terdapat beberapa risiko kekerasan yang dialami gay, yaitu risiko kekerasan fisik, psikologis/emosional, seksual, ekonomi, dan verbal. Risiko fisik yang dialami gay berupa dilempar senjata tajam, dipukul dan ditempeleng, seksual seperti diraba-raba bagian tubuh korban. Ekonomi seperti dimintai uang dan barang secara paksa. Gay juga mengalami risiko kekerasan verbal yaitu diumpati kata kasar, dibentak, diolok-olok dan diejek oleh masyarakat sekitar. Gay juga mengalami risiko kekerasan psikologis/emosional yang berupa dipandang sinis dan tidak suka, diusir, dan diancam dan stigma negatif terhadap komunitas gay.

Risiko kekerasan yang dialami gay menimbulkan beberapa dampak, yaitu secara fisik dan psikis. Secara fisik korban mengalami luka dan merasa sakit seperti rasa perih, pusing, dan memar pada bagian tubuh yang mengalami kekerasan. Sedangkan secara psikis menimbulkan rasa tidak terima, kecewa, sakit hati, dendam, marah, dan kesal, bahkan sampai korban mengalami trauma. Selain itu, dalam penelitin ini juga mengidentifikasi reflexive modernity, yang berupa tindakan dalam upaya menangani, mengurangi atau mengatasi dampak dari risiko. Dalam penelitian ini sejalan dengan pemikiran Ulrich Beck (1992) mengenai refleksivitas, gay secara mandiri dapat merespon kondisi atas risiko kekerasan yang tidak pasti (Demartoto, 2013). Gay yang merupakan anggota masyarakat korban dari risiko kemudian merefleksikan risiko kekerasan yang dialaminya. Gay berusaha mengatasi risiko kekerasan dengan berbagai upaya sebagai bentuk respon atas kekerasan. Gay menjadi lebih waspada dalam berinteraksi dengan masayarakat, mencari kenalan atau pasangan dengan lebih selektif, agar tidak kekerasan itu tidak terulang lagi. Pentingnya pembawaan diri di masyarakat untuk membangun kedekatan dengan masyarakat dengan melakukan berbagai bentuk kegiatan positif serta beradaptasi secara sosial di lingkungan masyarakat. Membangun citra diri dengan masyarakat dengan melakukan kegiatan kemasyarakatan. Kemudian lebih hati-hati dalam melakukan aktivitas homoseksual, seperti memenuhi kebutuhan seksualnya dengan langsung di tempat yang sudah dikenal dan tidak mangkal di tempat terbuka dan yang sudah diketahui ormas. Selain itu, advokasi agar mendapat keadilan hukum bagi gay korban 
kekerasan yang dilakukan oleh komunitas gay di Surakarta. Namun, upaya dalam menangani risiko ini memunculkan ketidakpastian baru atau masalah baru sebagai efek boomerang. Upaya gay dalam mengatasi risiko ini belum ada jaminan dari pemerintah. Belum adanya peraturan pemerintah yang jelas untuk menjamin dan melindungi keberadaan gay yang menahan upaya meminimalisir risiko kekerasan.

\section{DAFTAR PUSTAKA}

Adams, H.E.; Wright, L.W.; \& Lohr, B. A. (1996). Is Homophobia Associated WithHomosexual Arousal? Journal of Abnormal Psychology.

Allgeier, E.R \& Allgeier, A.R. (1991). Sexual Interacions (Third edition). Lexington: D.C. Healt and Company.

Apriliani, P; Santosa, B. (2018). Pemanfaatan Media Sosial dalam Relasi Sexual Kaum Gay. Journal of Development and Social Change, 1 (2).

Beck, Ulrich. (1992). Risk Society : Towards a New Modernity. London: Sage Publications.

Dank, M. (2013). Dating Violence Experiences of Lesbian, Gay, Bisexual, and Transgender Youth. Journal of Youth and Adolescence, Volume 43, Issue 5 , 846-857.

Demartoto, A. (2010). Mengerti, Memahami Dan Menerima Fenomena Homoseksual. Materi Dosen Jurusan Sosiologi FISIP UNS . Dipetik Oktober 24, 2018, dari http://argyo.staff.uns.ac.id/files/2010/08/seksualitas-undip.pdf

(2013).Teori Masyarakat Risiko dari Ulrich Beck. Materi Dosen Jurusan Sosiologi FISIP UNS. Dipetik dari http://argyo.staff.uns.ac.id/2013/03/14/teorimasyarakat-risiko-dari-ulrich-beck/

Harianjogja.com. (2016). Kaum Gay di Solo Diklaim Capai 5.000 Orang. Dipetik Maret 2, 2018, dari http://www.harianjogja.com/baca/2016/02/20/fenomena-lgbt-kaum-gaydi-solo-diklaim-capai-5-000-orang-693281

Kartono, Kartini. (1989). Psikologi Abnormal dan Abnormalitas Seksual. Bandung: PT. Mandar Maju.

Levy, Brian L. (2017). When love meets hate: The relationship between state policies on gay and lesbian rights and hate crime incidence. Social Science Research, Volume 61, 142-159.

Messerschmidt, J. W. (2012). Gender, Heterosexuality, and Youth Violence: The Struggle for Recognition. Maryland: Rowman \& Littlefield Publishers, Inc.

Oetomo, Dede. (2001). Memberi Suara Pada Yang Bisu. Yogyakarta: Galang Press.

Putri, R. R. (2012). Kekerasan Dalam Berpacaran. Skripsi Fakultas Psikologi Universitas Muhammadiyah Surakarta.

Sindhunata. (2000). Menuju Masyarakat Risiko. Jurnal Basis, Januari-Februari 2000, No. 0102, Tahun ke 49.

Tempo.co. (2016). 89,3 Persen LGBT di Indonesia Pernah Alami Kekerasan. Dipetik Oktober 3, 2018, dari nasional.tempo.co: https://nasional.tempo.co/read/739961/893-persen-lgbt-di-indonesia-pernah-alamikekerasan

Wahyuni, S. (2012). Kekerasan pada Gay di Surakarta : Bentuk dan Usaha-usaha Gay dalam Menghadapinya. Skrispi Jurusan Sosiologi FISIP Universitas Sebelas Maret Surakarta.

Woodford, M.R. (2014). Discrimination and Mental Health Among Sexual Minority College Students: The Type and Form of Discrimination Does Matter. Journal of Gay \& Lesbian Mental Health, 142-163. 